\title{
RESILIENSI SOSIAL TERKAIT AKSES SUMBER DAYA MASYARAKAT NELAYAN : PERSPEKTIF POLITICAL ECOLOGY
}

Malikkul Shaleh ${ }^{1}$, Oekan S. Abdoellah², dan Yayat Dhahiyat ${ }^{2}$

${ }^{1}$ Mahasiswa Pasca Sarjana Magister Ilmu Lingkungan, Unpad

${ }^{2}$ Dosen Pasca Sarjana Ilmu Lingkungan Unpad

Email : psmil@unpad.ac.id

\begin{abstract}
ABSTRAK. Resiliensi telah banyak digunakan sebagai aspek penting dalam pengelolaan sumber daya alam dan lingkungan karena merupakan atribut vital yang mencirikan kapasitas suatu sistem untuk mengatasi tekanan. Namun upaya untuk mempromosikan resiliensi tidaklah mudah terutama jika diterapkan pada konteks commonpool resources (CPRs) yang cenderung bersifat open access dan sangat kontes diantara banyak kepentingan. Penelitian ini dilakukan di Kelurahan Kamal Muara, Jakarta Utara dengan tujuan untuk mengetahui bagaimana resiliensi sosial masyarakat nelayan dalam mengatasi tekanan yang bersumber dari perubahan lingkungan, sosialekonomi, dan politik. Penelitian ini menggunakan metode campuran melalui strategi eksploratoris sekuensial untuk mengkaji beberapa indikator diantaranya kondisi ekologi-sosial lokal, mekanisme akses, flexibility, capacity to organize dan capacity to learn. Pada tahap kualitatif, data diperoleh dengan melakukan pengamatan, wawancara, dan penelusuran dokumen/internet untuk kemudian dianalisis menggunakan teknik analisis model interaktif dan analisis skenario. Hasil analisis tahap kualitatif kemudian digunakan sebagai acuan untuk melakukan survai menggunakan kuesioner yang kemudian dianalisis menggunakan teknik statistik deskriptif. Penelitian ini menggunakan perspektif political ecology sebagai kerangka kerja dan panduan dalam penafsiran hasil analisis. Hasil penelitian ini menunjukkan bahwa terbangunnya resiliensi masyarakat nelayan di Kamal Muara dipengaruhi oleh serangkaian mekanisme dalam mendapatkan, mengendalikan dan memelihara akses kepada sumber daya pesisir. Mekanisme akses, flexibility dan capacity to organize masyarakat nelayan di Kamal Muara terbatas sehingga hanya sedikit berkontribusi kepada level resiliensi mereka, terutama jika empat skenario tekanan (pencemaran perairan laut, musim ekstrim, kenaikan harga BBM, dan reklamasi pantai) terjadi secara simultan. Keterkaitan antara akses dan resiliensi tidak hanya memberikan pemahaman tentang masa yang dibutuhkan untuk pulih dari tekanan akibat perubahan ekologi-sosial, bahkan lebih dominan adalah tentang politics of access dimana hal ini sangat dibutuhkan untuk meningkatkan resiliensi sosial. Artinya, kebijakan sebagai sumber sekaligus produk politik ternyata memiliki peran strategis dalam upaya mempromosikan resiliensi dari sistem ekologi-sosial di wilayah pesisir yang sarat kepentingan.
\end{abstract}

Kata kunci : resiliensi, political ecology, akses, nelayan skala kecil, sumber daya pesisir

\section{SOCIAL RESILIENCE RELATED FISHER COMMUNITY'S ACCESS TO COASTAL RESOURCES: POLITICAL ECOLOGY PERSPECTIVE}

ABSTRACT. Resilience has been widely used as an important aspect in the management of natural resources and environment because it is a vital attribute that characterizes system's capacity to cope with pressure. However, an effort to promote resilience is not easy, especially when it is applied to the context of natural resource which in fact is open access and contests among many interests. This research was conducted in Kamal Muara, North Jakarta, in order to find out how the social resilience of fishing communities to overcome the pressures that basiclly is derived from environment, socio-economic, and political changes. Using a mixed method through sequential exploratory strategy, several indicators such as local social-ecological conditions, the mechanism of access, flexibility, capacity to organize and capacity to learn, are analyzed. In the qualitative phase, the data is obtained by observation, interview, and document review. The data is analyzed by using an interactive model analysis and scenario analysis. Then, the qualitative phase analysis result are used as a reference to do a survey, which are analyzed by using descriptive statistical techniques thereafter. This research uses a political ecology perspective as a framework and guide in result interpretation. The results suggest that the establishment of fishing community resilience in Kamal Muara influenced by a range of mechanisms to gain, control and maintain access to coastal resources. Their mechanisms of access, flexibility and capacity are limited so it is only give a little contribution to their resilience levels, especially if the four scenarios of pressure (marine pollution, extreme seasons, rising fuel prices, and reclamation) occur simultaneously. The linkage between access and resilience is not only provide an insight period that required for stress recovery from social-ecological change, even more it is about the politics of access where it is needed mostly to improve their social resilience. That is, the policy as a source and political product has a strategic role in promoting the resilience of social-ecological systems in coastal areas that highly contest.

Keywords: resilience, political ecology, access, small-scale fisher, coastal resource management

\section{PENDAHULUAN}

Lingkungan pesisir di Indonesia telah mengalami perubahan yang cepat dalam beberapa dekade belakangan ini. Perubahan tersebut pada dasarnya adalah akibat pesatnya laju pembangunan yang semata-mata bertujuan untuk meningkatkan taraf hidup masyarakat sehingga tidak terlepas dari berbagai macam aktivitas pemanfaatan sumber 
daya pesisir. Sederhananya, semakin tinggi laju pembangunan, maka semakin tinggi tingkat pemanfaatan sumber daya alam dan akhirnya makin besar pula perubahan yang terjadi pada lingkungan. Namun di sisi lain, pemanfaatan sumber daya ternyata memberikan tekanan kepada lingkungan pesisir sehingga berpotensi mengancam resiliensi sistem ekologi-sosial yang terdapat di dalamnya (Gowing et al., 2006). Resiliensi adalah kemampuan dari sistem ekologi atau sistem ekologi-sosial tertentu untuk dapat bertahan dari gangguan dengan cara menyerap dan mengarahkannya sehingga keadaan variabel dalam sistem tidak berubah (Holling, 1973; Folke, 2006). Pada konteks sistem sosial, kemampuan tersebut bisa berasal dari suatu komunitas tertentu dalam upayanya mengatasi berbagai tekanan eksternal sebagai akibat perubahan lingkungan, sosial, dan politik (Adger, 2000). Indikasi terkikisnya resiliensi sistem ekologisosial pesisir dapat dilihat dari permasalahan yang umum terjadi di wilayah pesisir seperti pencemaran laut, degradasi fisik habitat, over-eksploitasi sumber daya, konversi kawasan lindung, dan konflik sumber daya (Dahuri et al., 2004). Situasi ini membuat wilayah pesisir menjadi apa yang disebut Wibowo (1988) sebagai depressed area.

Munculnya berbagai macam permasalahan tadi menandakan bahwa wilayah pesisir kaya akan keanekaragaman fungsi, mulai dari fungsi ekologi, sosial sampai kemajemukan relung ekonomi. Kondisi tersebut secara tidak langsung telah membuat wilayah pesisir menjadi suatu ekosistem yang beresiliensi tinggi (Adger, 1997). Namun upaya membangun atau mempertahankan resiliensi dari suatu sistem bukanlah perkara mudah karena perubahan dimasa depan itu sendiri sangat sulit diprediksi bahkan cenderung mengejutkan sehingga berpotensi untuk terus mengganggu stabilitas sistem (Holling, 2001).

Terlebih jika dikaitkan dengan resiliensi sistem ekologi-sosial pada konteks common-pool resources (CPRs) seperti wilayah pesisir yang disatu sisi kaya akan fungsi namun di sisi lain tinggi akan tingkat pemanfaatan sumber dayanya. Hal ini menjadi semakin rumit karena CPRs sendiri pada dasarnya adalah barang publik yang terbatas dan cenderung dimanfaatkan secara bebas dan tak terkendali oleh semua orang dengan kepentingannya masing-masing sehingga berpotensi mengalami degradasi (Wade, 1987). Kondisi ini tentu menjadi dilema tersendiri bagi pengelola atau pembuat kebijakan untuk akhirnya menjawab pertanyaan sentral seperti yang dikemukakan Fabinyi (2008) yaitu : "Bagaimana mungkin kita bisa mempromosikan resiliensi pada suatu sistem ekologi-sosial yang dimana sistem itu sendiri terbentuk dari berbagai macam kontestasi kepentingan manusia?"

Kecenderungan akan sulitnya mengelola CPRs tersebut telah lama digambarkan oleh Gareth Hardin (1968) dalam tulisan terkenalnya berjudul "Tragedy of The Commons". Hardin (1968) dalam Ostrom (2002) mengatakan bahwa jika suatu CPRs yang bernilai dibiarkan menjadi open access maka dapat dipastikan akan terjadi overeksploitasi dan akhirnya terdegradasi. Untuk mengatasi tragedi yang "tak terhindarkan" tersebut, Hardin kemudian menawarkan gagasan, yaitu dengan memberlakukan rejim full private property rights atau state property rights pada CPRs yang bertujuan agar hak pemanfaatan "the common" dapat dialokasikan dan diatur secara efektif (Hardin, 1978 dalam Feeny et al., 1990). Gagasan ini selintas memang nampak sederhana dan secara tidak langsung berpotensi menciptakan sistem yang stabilsebagai syarat untuk membangunan resiliensi. Namun gagasan Hardin ini nyatanya tidak selalu berjalan baik sebab banyak dari upaya untuk pengelolaan CPRs selama ini cenderung diwarnai dengan konflik antar pemilik kepentingan (German, 2010) sehingga nampak kontra produktif dengan gagasannya.

Sejak awal kemunculannya, gagasan Hardin (1968) memang telah memunculkan perdebatan terkait beberapa hal : Pertama, terkait konsep open access dan common-property. Hardin cenderung mengasumsikan rejim common-property sebagai "free-for-all" sehingga menyebabkan terjadinya degradasi sumberdaya, padahal common-property tidaklah open access; Kedua, kesimpulan akan tragedi yang "tak terhindarkan" cenderung menyederhanakan aspek sejarah dan sosialbudaya terkait kemampuan rejim common-property dalam mengelola CPRs (Bromley dan Cernea, 1989; Ostrom, 2002). Padahal banyak hasil penelitian dari Elinor Ostrom dan kolega yang menemukan bahwa groups of users masyarakat tradisional pada rejim common-property nyatanya dapat mengelola, menggunakan, dan mengalokasikan CPRs secara lebih berkelanjutan dengan didukung oleh seperangkat institusi pada situasi dimana private property rights terkadang gagal melakukannya (Feeny et al., 1990; German, 2010).

Terlepas dari ambiguitas pemahaman Hardin mengenai peleburan makna open acces dan common-property, Bryant dan Bailey (1997) melihat bahwa gagasan tentang privatisasi tersebut hanyalah upaya justifikasi negara terhadap rejim common-property yang dianggap tidak mampu atau tepatnya tidak mengelola CPRs dengan baik. Akibatnya, gagasan tersebut bukannya menyelesaikan "Tragedy of The Commons" tapi justru memicu terjadinya "Tragedy of Enclosure" karena seringnya praktik pengambil alihan penguasaan sumber daya seperti dari masyarakat tradisional oleh negara dengan motif komersialisasi maupun konservasi tanpa mengindahkan hak dan akses mereka. Akhirnya, masyarakat pun menjadi korban dan termarjinalkan, baik karena hilangnya akses mereka maupun karena munculnya situasi dimana mereka harus terus bertahan hidup pada lingkungan yang telah terdegradasi. Kondisi ini tentu sangat tidak adil bagi masyarakat. Namun apalah daya, masyarakat tetap tidak dapat berbuat banyak mengingat lemahnya kekuatan dan posisi politik mereka jika harus melawan "aktor dominan" negara (state) dan atau pasar (market) (Adger et al., 2001; Satria, 2009). 
Fenomena "Tragedy of Enclosure" secara tidak langsung dapat mempengaruhi resiliensi sosial dan pada tingkat tertentu dapat memicu kerentanan sosial. Hal ini karena resiliensi sosial dapat tercermin dari bagaimana cara suatu kelompok masyarakat memperoleh, mengontrol, dan memelihara akses atas sumber daya yang kritis bagi kelangsungan hidup mereka (Langride et al., 2006). Tanpa jaminan akses sumber daya maka resiliensi sosial akan melemah dan akhirnya dapat menjadikan mereka rentan bahkan marjinal. Hanya dengan upaya pengamanan akses terhadap sumber daya tersebutlah resiliensi sosial dapat dibangun dan dipertahankan (Ratner, 2011). Namun hal itu tentu tidaklah mudah untuk diwujudkan mengingat permasalahan akses sumber daya sangat dipengaruhi oleh perubahan kompleks dari tidak hanya sistem ekologi-sosial lokal namun juga oleh konstelasi sosial-politik pada skala yang lebih luas.

Wilayah pesisir Teluk Jakarta adalah salah satu dari banyak contoh kasus di Indonesia yang menggambarkan tentang bagaimana laju pembangunan telah begitu cepatnya menggerus resiliensi sistem ekologi-sosial. Hal ini ditandai dengan telah berkurangnya luas hutan mangrove, rusaknya terumbu karang serta tercemarnya perairan pesisir sebagai dampak dari alih fungsi lahan pesisir, over-eksploitasi sumber daya laut, dan pembuangan limbah yang berlangsung tanpa terkendali. Disisi lain, sementara kondisi lingkungan semakin tertekan, terdapat sekelumit masalah pemanfaatan sumber daya yang juga muncul mewarnai perubahan pesisir Teluk Jakarta. Masalah tersebut ternyata menjadi semakin kompleks karena akhirnya berkembang dan memunculkan kontestasi antar pengguna sumber daya, yaitu antara negara, pemilik modal dan masyarakat nelayan. Namun nelayan tidak bisa berbuat apa-apa. Alhasil wacana populis yang muncul, nelayan tetap saja menjadi korban (Satria, 2009) karena menempati posisi paling lemah dalam politicised environment sebagai aktor akar rumput (grassroot) (Bryant dan Bailey, 1997) sebagaimana terlihat dari ketidakmampuannya dalam mempengaruhi berbagai kebijakan yang jelas mengekang akses mereka seperti kebijakan reklamasi pantai Teluk Jakarta.

Armitage (2008) mengatakan bahwa untuk dapat mengelola CPRs pada "multi-level world" seperti sekarang ini dibutuhkan kebaruan dan inovasi, tidak justru melalui pengelolaan konvensional yang bersifat top down dan parsial ekonomistis semata. Pengelolaan harus dilakukan secara terpadu dan integral komprehensif dengan mempertimbangkan resiliensi dari sistem ekologi-sosial dan konstelasi sosial-politik yang melingkupinya sehingga memungkinkan kita membangun kapasitas untuk mentransformasi masalah pengelolaan CPRs yang selama ini problematik. Konsekuensinya, kebijakan sebagai instrument utama pengelolaan harus melihat hal tersebut sebagai sesuatu yang perlu menjadi pertimbangan.

\section{METODE}

Penelitian ini menggunakan perspektif political ecology untuk menelurusi isu terkait akses dan pengelolaan sumber daya pesisir yang kemudian dikaitkan dengan teori resiliensi. Metode penelitian yang digunakan pada penelitian ini adalah metode campuran (mixed) dengan strategi eksploratoris sekuensial, dimana melibatkan pengumpulan dan analisis data kualitatif pada tahap pertama, yang kemudian diikuti oleh pengumpulan dan analisis data kuantitatif pada tahap kedua yang didasarkan pada hasil-hasil tahap pertama. Penelitian ini dilaksanakan selama 2 (dua) bulan di RW 1 dan 4 Kelurahan Kamal Muara, Penjaringan, Jakarta Utara. Kamal Muara dipilih sebagai lokasi penelitian karena daerah yang memiliki perkampungan pesisir yang sebagian besar penduduknya merupakan kelompok nelayan tangkap dan petambak kerang hijau. Pengumpulan data dilakukan dengan menggunakan beberapa teknik, diantaranya : pengamatan, wawancara, survai, dan dokumenter/internet. Data yang terkumpul kemudian dianalisis dengan menggunakan beberapa teknik analisis, diantaranya : analisis interaktif, analisis skenario, dan analisis statistik deskriptif.

\section{HASIL DAN PEMBAHASAN}

\section{Perubahan Kondisi Ekosistem dan Sumber Daya Pesisir}

Secara umum, kondisi ekosistem dan sumber daya pesisir telah mengalami degradasi dan penurunan kualitas. Hal ini ditandai dengan telah berkurangnya luas hutan mangrove, rusaknya terumbu karang serta tercemarnya perairan pesisir sebagai dampak dari alih fungsi lahan pesisir, over-eksploitasi sumber daya laut, dan pembuangan limbah yang berlangsung tanpa terkendali terutama semenjak adanya kebijakan pembangunan ekonomi oleh pemerintah pusat dengan menjual lahan bekas tambak untuk keperluan industri pada tahun 1980-an. Status ekosistem pesisir DKI Jakarta dapat dilihat pada Tabel 1.

Tabel 1. Status Ekosistem Pesisir di DKI Jakarta

\begin{tabular}{lll}
\hline Ekosistem & Status & \multicolumn{1}{c}{ Keterangan } \\
\hline Mangrove & Menurun & $\begin{array}{l}\text { Luasan berkurang secara signifikan } \\
\text { dalam kurun waktu 42 tahun dengan } \\
\text { tingkat penurunan luas sekitar 1.102 } \\
\text { hektar, atau sekitar } 80 \% \text { dari seluas } \\
\text { 1.334,62 Ha pada tahun 1960. }\end{array}$ \\
& & Dalam 20 tahun terakhir, sekitar65 - 80 \\
Terumbu & Menurun & \%arang hidup di Kepulauan Seribu \\
Karang & & telah rusak. Status terumbu karang \\
& & berada dalam kondisi buruk hingga \\
& & sedang dengan tutupan karang berkisar \\
& & 13.0\% hingga 36.0\%. \\
Padang & Meningkat & luasnya tercatat mengalami peningkatan \\
Lamun & & yang cukup signifikan dari hanya seluas \\
& & 2.81,5 Ha tahun 1999, menjadi sekitar \\
& & $16.036,78$ Ha padatahun 2011. \\
\hline
\end{tabular}

Sumber : Arifin (2004);BPLHD DKI Jakarta (2011) 
Taksiran potensi lestari sumber daya perikanan di perairan Utara Jawa untuk jenis ikan tersebut adalah sebesar 569.152 ton/tahun (Dahuri et al., 2004). Sedangkan taksiran untuk di perairan sekitar Teluk Jakarta tidak sebesar angka tersebut dan bahkan diduga telah mengalami lebih tangkap (over fishing) (Hutagalung dan Nontji, 1995) Penggunaan alat tangkap yang tidak ramah lingkungan adalah salah satu penyebab lain terjadinya lebih tangkap dan kerusakan lingkungan pesisir di Teluk Jakarta (Sudin P2K Jakarta Utara, 2012). Kecenderung lebih tangkap ini terutama terjadi pada perikanan pesisir dan pantai (Arifin, 2004). Hal ini tidak lepas dari kondisi perairan Laut Jawa yang juga telah mengalami lebih tangkap terutama untuk jenis ikan pelagis kecil (Suyasa et.al, 2007).

\section{Keterkaitan Akses dan Resiliensi}

Berdasarkan hasil analisis mengenai kondisi lingkungan, sosial, dan politik yang melingkupi aktivitas nelayan Kamal Muara, maka teridentifikasi 4 (empat) skenario tekanan yang berpotensi mengancam keberlanjutan usaha nelayan Kamal Muara, yaitu :

1) Pencemaran perairan Teluk Jakarta semakin parah. Indikasi ini dapat dilihat dari upaya pengelolaan limbah di perairan Teluk Jakarta yang sampai saat ini belum berjalan optimal dan kecenderungan akan bertambahnya jumlah hunian, kawasan industri dan aktivitas pembangunan lain di wilayah hulu maupun pesisir pantai.

2) Kondisi musim ekstrim berlangsung lama. Kondisi seperti musim baratan pada tahun 20072008 besar kemungkinan dapat terjadi kembali. Faktor perubahan iklim menjadi faktor yang dominan kendati cenderung sulit diprediksi. Naylor et al. (2007) dalam Priambodo (2009) menyebutkan bahwa perubahan iklim regional mengindikasikan bahwa terdapat kemungkinan bagi angin monsoon untuk mulai satu bulan lebih awal setiap tahun namun lebih lama hingga bulan April atau Juni dengan peningkatan curah hujan sebesar $10 \%$. Indikasi ini telah dirasakan oleh nelayan bagan apung di Kamal Muara yang telah 4 (empat) bulan tidak melaut karena kondisi cuaca di perairan laut.

3) Harga BBM kembali mengalami kenaikan. Harga BBM memang telah ditetapkan naik per Juni 2013, namun kemungkinan untuk kembali mengalami kenaikan tetap ada kendati dalam jangka panjang. Hal ini berangkat dari tren fluktuasi harga minyak dunia dan kondisi politik Timur Tengah yang sedikit banyak memiliki pengaruh terhadap pergerakan harga minyak dunia.

4) Penggusuran wilayah tangkap untuk keperluan reklamasi pantai. Perda DKI Jakarta No.1/2012 tentang Rencana Tata Ruang Wilayah 2030 telah memasukkan wilayah perairan pesisir Kecamatan Penjaringan sebagai salah satu yang akan direklamasi. Hal ini terlihat dari upaya sosialisasi dan negosiasi yang telah dilakukan pemerintah akhir tahun 2012 agar pembudidaya kerang hijau di Kamal Muara tidak lagi beroperasi di perairan Teluk Jakarta dan Kepulauan Seribu.

Status nelayan Kamal Muara yang tergolong nelayan kecil membuat mereka bebas untuk menangkap ikan sebagaimana diatur dalam undangundang. Artinya, hak akses dan hak menangkap ikan (right-based access) mereka secara de jure telah terjamin, kendati kebebasan itu sendiri tetap harus sesuai dengan ketentuan yang berlaku. Dari waktu ke waktu, mereka menggunakan serangkaian mekanisme dalam rangka memelihara dan mengontrol akses yang meliputi teknologi, modal, pasar, dan pengetahuan. Bagi mereka, mekanismemekanisme tersebut sudah cukup jika hanya sekedar ingin memperoleh sedikit keuntungan dari menangkap ikan. Namun jika keempat skenario tersebut tadi terjadi secara simultan lalu kemudian menurunkan ketersediaan sumber daya ikan disatu sisi dan pendapatan nelayan di sisi yang lain, cukup nampaknya akan menjadi hal yang sangat "langka" bagi mereka. Hal ini karena diketahui bahwa mekanisme-mekanisme akses mereka sendiri ternyata terbatas seperti yang secara ringkas dapat dilihat pada Tabel 2 sehingga memberikan sedikit resiliensi atas tekanan akibat penurunan sumber daya ikan serta pendapatan.

Gambaran tentang resiliensi sosial atau kemampuan nelayan Kamal Muara dalam menanggulangi dan mengadaptasi tekanan yang mengancam keberlanjutan usahanya ternyata dipengaruhi oleh serangkaian mekanisme untuk mendapatkan, mengendalikan dan memelihara akses terhadap sumber daya. Sebenarnya pada kondisi ideal, akses sumber daya yang baik dan terjamin dapat secara otomatis menguatkan resiliensi sosial. Namun, hasil penelitian ini menemukan hasil yang bertolak belakang dimana resiliensi sosial mereka dalam kondisi yang bisa dikatakan lemah karena terbatasnya akses dan cenderung akan semakin melemah, terutama jika keempat skenario tekanan terjadi. Skenario yang paling mengancam akses dan begitu pula resiliensi nelayan Kamal Muara sebenarnya adalah terkait kebijakan reklamasi pantai. Hampir tidak ada yang bisa dilakukan untuk mengantisipasi skenario ini. Hal ini terbukti dari penggusuran wilayah tangkap nelayan Kamal Muara yang terjadi sebelumnya. Apalagi secara legal formal, rencana reklamasi tersebut kini mulai jelas sebagaimana tertera dalam RTRW DKI Jakarta 2012-2030. Jangankan bagi nelayan yang lemah secara sosial-politik, bahkan ogranisasi setingkat KLH, DPR, MA atau LSM-LSM lingkungan yang berada didekat lingkar kekuasaan sekalipun tidak mampu untuk melawan kebijakan tersebut. Lebih jauh kebijakan reklamasi ini dapat membuat mereka rentan dan besar kemungkinan marjinal. Bahkan tidak menutup kemungkinan cepat atau lambat akan terjadinya apa yang oleh Priambodo (2009) ramalkan yaitu "kepunahan" nelayan 
Tabel 2. Keterkaitan Akses dan Resiliensi

\begin{tabular}{|c|c|}
\hline Indikator & Kondisi \\
\hline \multicolumn{2}{|c|}{ Mekanisme Akses } \\
\hline Right-based & $\begin{array}{l}\text { Terbatas kendati secara de jure } \\
\text { dilindungi }\end{array}$ \\
\hline Teknologi & Skala kecil (Post-traditional) \\
\hline Modal & Skala kecil dan terbatas \\
\hline Pasar & Subsistensi untuk pasar domes tik \\
\hline Tenaga kerja & $\begin{array}{l}\text { Perorangan dan terbatas pada } \\
\text { level lokal }\end{array}$ \\
\hline Pengetahuan & $\begin{array}{l}\text { Lokal knowledgesystem tanpa } \\
\text { scientific expertise }\end{array}$ \\
\hline Identitas sosial & Non-adat (tidak digunakan) \\
\hline Kewenangan & Terbatas (tidak digunakan) \\
\hline \multicolumn{2}{|l|}{ Potensi Resiliensi } \\
\hline \multicolumn{2}{|c|}{ Lemah - Tidak adabentuk jaminan akses } \\
\hline
\end{tabular}

\section{Implikasi Kebijakan}

Kasus nelayan Kamal Muara ini memberikan gambaran penting tentang keterkaitan antara akses dan resiliensi. Keduanya tidak hanya memberikan pemahaman tentang masa yang dibutuhkan untuk pulih dari tekanan akibat perubahan ekologi-sosial, tapi juga-bahkan lebih dominan-politics of access dimana hal ini ternyata sangat krusial dibutuhkan untuk meningkatkan resiliensi mereka. Artinya, kebijakan sebagai sumber sekaligus produk politik ternyata memiliki peran sentral dan strategis dalam upaya mempromosikan resiliensi pada sistem ekologisosial di wilayah pesisir yang dikenal sangat contest. Hal ini kemudian memunculkan konsekuensi bagi suatu kebijakan untuk dapat mengakomodir semua kepentingan stakeholder di wilayah pesisir termasuk kelompok nelayan. Pengakomodiran kepentingankepentingan di dalam suatu kebijakan seyogyanya tidak berlandaskan pada paradigma pembangunan yang konvensional dimana cenderung top down dan berorientasi ekonomi semata-sebagaimana seperti temuan penelitian ini maupun yang secara umum terjadi di Indonesia. Namun harus berlandaskan paradigma baru yang lebih baik, yaitu pelaksanaan konsep pembangunan berkelanjutan dan pengelolaan lingkungan wilayah pesisir secara terpadu. Perubahan paradigma pembangunan disisi lain menuntut adanya beberapa pertimbangan yang berkaitan dengan bagaimana proses pembuatan dan pelaksanaan kebijakan berjalan hingga akhirnya memberikan dampak positif kepada suatu sistem ekologi-sosial. Dengan kata lain-merujuk pada fokus penelitian iniout put suatu kebijakan pada akhirnya harus dapat mendukung terbangunnya resiliensi sistem ekologisosial bukan justru mengikisnya.

Penekanan aspek politik dalam upaya meningkatkan resiliensi komunitas di wilayah pesisir menjadi penting mengingat kontestasi akses dan pemanfaatan sumberdaya di wilayah ini sangat tinggi (Ratner et al., 2010). Oleh karena itu, segala upaya yang akan dilakukan untuk mempromosikan resiliensi ekologi-sosial harus pula dilihat sebagai konsep politik karena resiliensi tidak bisa dipisahkan dari kebutuhan akan keputusan-keputusan politik dan upaya negosisasi antara bermacam-macam aktor sehingga politik harus masuk menjadi salah satu aspek resiliensi jika ingin suatu praktik pengelolaan atau konsep kebijakan sukses (Fabinyi, 2008). Upaya ini mungkin akan bisa menjawab pertanyaan fundamental tentang kemungkinan untuk bisa menyeimbangkan antara banyaknya kepentingan dengan keberlanjutan ekologi dalam rangka membangun sistem yang resilien. Lebih khusus sebagai upaya untuk meningkat resiliensi sosial, penempatan kepentingan nelayan yang sejajar dengan atau mungkin lebih dari kepentingan aktor lain dalam suatu kebijakan menjadi catatan penting sebagaimana tercermin dalam prinsip-prinsip dasar pengelolaan wilayah pesisir secara terpadu dan berkelanjutan, bahwa pemanfaatan sumber daya pesisir laut harus diprioritaskan untuk meningkatkan kesejahteraan masyarakat terutama mereka yang tergolong ekonomi lemah sehingga mendorong terwujudnya suatu keadilan sosial.

\section{SIMPULAN}

Gambaran tentang bagaimana terciptanya resiliensi nelayan Kamal Muara ternyata berkaitan dengan kemampuan mereka dalam mengakses sumber daya yang sangat kritis bagi keberlanjutan usaha dan kehidupan mereka, yaitu sumber daya pesisir. Akses mereka ini sendiri dipengaruhi oleh berbagai tekanan akibat perubahan lingkungan, sosial-ekonomi, dan politik yang terjadi pada skala lokal, regional maupun global melalui dampaknya kepada hasil tangkapan ikan dan kesempatan akses. Resiliensi nelayan Kamal Muara saat ini berada pada level yang lemah, tidak hanya karena terbatasnya beberapa mekanisme akses seperti teknologi, modal, pasar dan right-based access, namun juga karena tidak digunakannya mekanisme akses melalui identitas sosial dan kewenangan untuk mengendalikan dan memelihara akses. Level resiliensi nelayan Kamal Muara berpotensi akan semakin melemah jika skenario pencemaran perairan laut, musim ekstrim, kenaikan harga BBM, dan reklamasi pantai terjadi secara simultan Keterkaitan antara akses dan resiliensi memberikan tidak hanya pemahaman tentang masa yang dibutuhkan untuk pulih dari tekanan akibat perubahan ekologi-sosial, tapi juga politics of access dimana hal itu ternyata sangat krusial dibutuhkan nelayan untuk meningkatkan level resiliensinya.

\section{DAFTAR PUSTAKA}

Adger, W.N. 1997. Sustainability And social Resilience In Coastal Resource Use. CSERGE Working Paper. University of East Anglia and University College London. London

2000. Social and Ecological Resilience: Are They Related?. Progress in Human Geography (24): 3.

Adger, W.N., T.A. Benjaminsen., K. Brown and H. Svarstad. 2001. Advancing a Political Ecology of 
Global Environmental Discourses. Development and Change (32): 681-715

Arifin, Z. 2004. Local Millenium Ecosystem Assessment: Condition and Trend of The Greater Jakarta Bay Ecosystem. Report Assessment Submitted to Assistant Deputy for Coastal and Marine Ecosystem. KLH. Jakarta

Armitage, D. 2008. Governance and the commons in a multi-level world. Internastional Journal of the Commons (2-1): 7-32

[BPLHD] Badan Pengelolaan Lingkungan Hidup Daerah DKI Jakarta. 2010. Laporan Status Lingkungan Hidup Daerah Tahun 2010. Pemerintah Provinsi Daerah Khusus Ibu Kota Jakarta.

Bryant, R. L. and S. Bailey. 1997. Third World Political Ecology. Routledge. London

Bromley, D.W and M.Cernea. 1989. The management of common property natural resources : some conceptual and operational fallacies. World Bank discussion papers (57)

Dahuri, R., J. Rais., S.P.T. Ginting., M.J. Sitepu. 2004. Pengelolaan Sumberdaya Pesisir dan Lautan Secara Terpadu. Pradnya Paramita. Jakarta

Fabinyi, M. 2008. The Political Aspect of Resilience. Proceedings of the 11th International Coral Reef Symposium. Florida, 7-11 July 2008

Feeny, D., F. Berkes., B.J. McCay and J.M. Acheson. 1990. The Tragedy of the Commons: Twenty-Two Years Later. Human Ecology (18) : 1

Folke, C. 2006. Resilience: the emergence of a perspective for social-ecological systems analyses. Global Environmental Change 16:253-267.

German, L.A. 2010. "Hybrid institutions": Applications of Common Property Theory Beyond Discrete Property Regimes. International Journal of the Commons (4-1): 571-596

Gowing, J.W., T.P. Tuong., and C.T. Hoanh. 2006. Land and Water Management in Coastal Zones: Dealing with Agriculture-Aquaculture-Fishery Conflicts. CAB International. Environment and Livelihoods in Tropical Coastal Zones
Holling, C. S. 1973. Resilience and stability of ecological systems. Annual Review of Ecology and Systematics (4):1-23.

2001. Understanding the Complexity of Economic, Ecological, and Social Systems. Ecosystems (4):390-405

Hutagalung, H.P dan A. Notji.1995. Masalah Pesisir dan Kelautan di Teluk Jakarta dan Kaitannya dengan Rencana Reklamasi. Makalah Lokakarya Reklamasi Teluk Jakarta. Jakarta, 23-24 Januari 1995

Ostrom, E. 2002. Common-Pool Resources and Institutions: Toward A Revised Theory. In B. Gardner and G. Rausser (ed.). Handbook of Agricultural Economics. Elsevier Science (2)

Priambodo, B.B. 2009. Preserve or Perish: A Scenario Analysis on the Future of Small-Scale Fishery in Jakarta Bay. Thesis. University of Maastricht. Maastricht

Satria, A. 2009. Ekologi Politik Nelayan. LkiS. Yogyakarta

Sudin P2K Jakarta Utara. 2011. Buku Saku Peternakan Perikanan dan Kelautan Jakarta Utara Tahun 2011.

Suyasa, I.N., M.F.A, Sondita., V.P.H., Nikijuluw., dan D.R., Monintja. 2007. Status Sumber daya Ikan Pelagis Kecil dan Faktor Penentu Efisiensi Usaha Perikanan di Pantai Utara Jawa. Buletin PSP XVI (2):

Ratner, B.D. 2011. Common-Pool Resources, Livelihoods, and Resilience: Critical Challenges for Governance in Cambodia. International Food Policy Research Institute Discussion Paper (01149)

Wade, R. 1987. The management of common property resources: collective action as an alternative to privatisation or state regulation. Cambridge Journal of Economis (11): 95-106

Wibowo, R. 1988. Studi Pembangunan Sumberdaya di Wilayah Pantai Utara Jawa Barat. Tesis. Institut Pertanian Bogor. Bogor 